\title{
Multiple Familial Trichoepithelioma
}

\section{Tricoepitelioma Múltiplo Familiar}

Ana Filipe MONTEIRO $\square^{1}$, Margarida RATO ${ }^{1}$, Pedro LUÍS ${ }^{2}$, Ermelindo TAVARES ${ }^{3}$

Acta Med Port 2018 Mar;31(3):180-180 - https://doi.org/10.20344/amp.10383

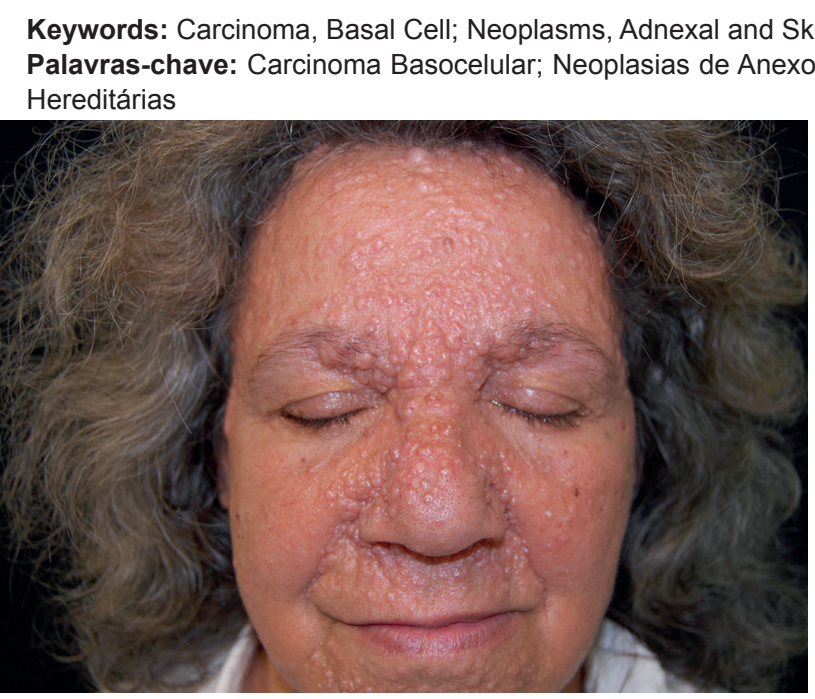

Figure 1 - Multiple skin-coloured papules and nodules located on the scalp, forehead, nose, nasolabial folds, and, perioral region characteristic from multiple familial trichoepithelioma

A 62-year-old woman presented with multiple skin-coloured papules and nodules on the scalp, face and intergluteal cleft which had developed slowly since childhood (Fig. 1). Her mother, three sisters and two daughters had similar lesions. Recently, she noticed a rapid enlargement of a $12 \mathrm{~mm}$ nodule on the right temporal area. Excision biopsy and histopathologic examination of a facial and sacral lesion revealed trichoepitheliomas (TE) (Fig. 2), whereas the temporal nodule was compatible with basal cell carcinoma (BCC). Genetic study showed a heterozygotic mutation in

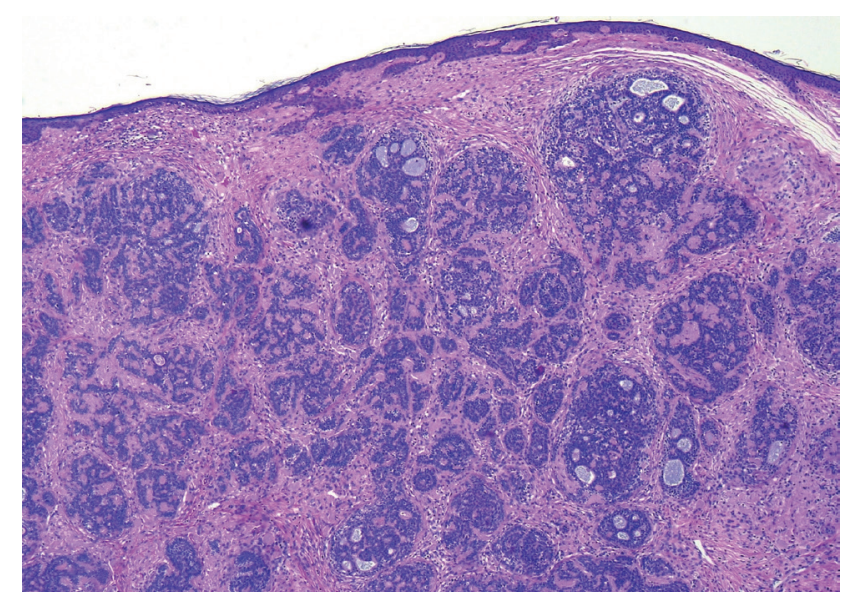

Figure 2 - Trichoepithelioma: multiple nodular proliferations of uniform basaloid cells with focal peripheral palisading and small keratin-filled cysts (H\&E, 40x)

exon 9 of $C Y L D$ gene [c.1112C >A(p.Ser371*)], supporting the diagnosis of multiple familial trichoepithelioma (MFT).

MFT is an uncommon autosomal-dominant genodermatosis characterized by multiple TE on the face, scalp and, neck with rare reports on other anatomical locations. ${ }^{1}$ The association of MFT with malignancy is rare, however, TE can infrequently undergo malignant transformation to BCC..$^{2-4}$ That is why these patients should be kept under long-term observation.

\section{PROTECTION OF HUMANS AND ANIMALS}

The authors declare that the procedures were followed according to the regulations established by the Clinical Research and Ethics Committee and to the Helsinki Declaration of the World Medical Association.

DATA CONFIDENTIALITY

The authors declare having followed the protocols in use at their working center regarding patients' data publication. Patient consent obtained. CONFLICTS OF INTEREST

All authors report no conflict of interest.

FUNDING SOURCES

This research received no specific grant from any funding agency in the public, commercial, or not-for-profit sectors.

\section{REFERENCES}

1. Heller J, Roche N, Hameed M. Trichoepithelioma of the vulva. J Low Genit Tract Dis. 2009;13:186-7.

2. Pincus LB, McCalmont TH, Neuhaus IM, Kasper R, Oh DH. Basal cell carcinomas arising within multiple trichoepitheliomas. J Cutan Pathol. 2008;35:5964.

3. Reddy KA, Satyanarayana MA, Aryasomayajula S, Krishna BA. Basal cell carcinoma developing from trichoepithelioma: review of three cases. J Clin Diagn Res. 2016;10:17-9.

4. Arits AH, Parren LJ, van Marion AM, Sommer A, Frank J, Kelleners-Smeets NW. Basal cell carcinoma and trichoepithelioma: a possible matter of confusion. Int J Dermatol. 2008;47:13-7.

1. Serviço de Dermatovenereologia. Hospital de Santarém. Santarém. Portugal.

2. Serviço de Anatomia Patológica. Hospital de Santarém. Santarém. Portugal.

3. Serviço de Dermatovenereologia. Hospital de Vila Franca de Xira. Vila Franca de Xira. Portugal.

$\square$ Autor correspondente: Ana Filipe Monteiro. anafilipemonteiro@gmail.com

Recebido: 09 de fevereiro de 2018 - Aceite: 05 de março de 2018| Copyright @ Ordem dos Médicos 2018 